\title{
Gambaran Pola Makan Lansia Obesitas dengan Hipertensi di Wilayah Kerja Puskesmas Tegalrejo Kota Salatiga
}

Kristiawan P.A. Nugroho*, Junet Franzisca da Costa, R.L.N.K. Retno Triandhini, Stefani Ratna Indriati

\begin{abstract}
Background: Obesity is one of the problems of non-communicable diseases that are still commonly found. Indonesia is one of the developing countries with high levels of obesity. Based on the Central Java Health Profile of 2015, the highest prevalence of obese population is found in Salatiga. Obesity increases the risk of high blood pressure or hypertension. Elderly are age group that can be obese and hypertension. Problems of Obesity and Hypertension can occur in the elderly can be caused by the wrong diet.
\end{abstract}

Objective: The study was conducted to examine the diet of elderly people with obesity with hypertension in the work area of puskesmas Tegalrejo.

Method: This research method using descriptive quantitative. The elderly respondents aged $>50$ years were selected based on secondary data from Tegalrejo Puskesmas with IMT calculation and hypertension identified. Data collection with structured interview using questionnaires, FFQ sheet feeding, and Food Recall. This research was carried out in February-April 2018. Data analysis includes questionnaire results from question items provided, then analyzed descriptively; the FFQ and Food Recall sheets were analyzed to obtain data on the types of foods routinely consumed within the observation period of the study, the frequency, the number of doses, the method of processing, and the calculation of nutrients and calories.

Result: Based on FFQ and Food recall fall into the category of deficit but based on anthropometry into more categories that affect diet.

Conclusion: Elderly diet obesity and hypertension tend to be less good and there are other factors that influence diet.

Keyword: Obesity, Hypertension, Diet, Elderly

Afiliasi Penulis

Universitas Kristen Satya Wacana

Korespondensi kepada

K.P.A. Nugroho

kristiawan.nugroho@staff.uksw.edu 


\section{Intisari}

Latar Belakang: Obesitas merupakan salah satu masalah penyakit tidak menular yang masih sering ditemukan. Indonesia merupakan salah satu negara berkembang dengan tingkat obesitas tinggi. Berdasarkan Profil Kesehatan Jawa Tengah tahun 2015, Prevalensi penduduk obesitas tertinggi terdapat di Salatiga. Obesitas meningkatkan resiko terjadinya penyakit tekanan darah tinggi atau hipertensi. Lansia merupakan kelompok umur yang dapat mengalami obesitas dan hipertensi. Masalah Obesitas dan Hipertensi dapat terjadi pada lansia dapat disebabkan pola makan yang salah.

Tujuan: penelitian dilakukan untuk mengkaji pola makan lansia penderita obesitas dengan hipertensi di wilayah kerja puskesmas Tegalrejo.

Metode: Metode penelitian ini menggunakan deskriptif kuantitatif. Responden lansia berusia $>50$ tahun dipilih berdasarkan data sekunder dari Puskesmas Tegalrejo dengan penghitungan IMT dan teridentifikasi hipertensi. Pengumpulan data dengan wawancara terstruktur menggunakan kuisioner, pengisian lembar FFQ, dan Food Recall. Penelitian ini dilaksanakan pada bulan Februari-April 2018. Analisis data meliputi hasil kuesioner dari item - item pertanyaan yang disediakan, kemudian dianalisis secara deskriptif; lembar FFQ dan Food Recall dianalisis untuk mendapatkan data terkait jenis makanan yang rutin dikonsumsi dalam kurun waktu pengamatan penelitian, frekuensi, jumlah takaran, cara pengolahan, serta penghitungan zat gizi dan kalori.

Hasil: Berdasarkan FFQ dan Food Recall masuk dalam kategori defisit tetapi berdasarkan antropometri masuk dalam kategori lebih yang dipengaruhi oleh diet.

Kesimpulan: Diet obesitas dan hipertensi pada lansia cenderung kurang baik dan ada faktor lain yang mempengaruhi diet.

Kata Kunci: Obesitas, Hipertensi, Diet, Lansia

\section{Pendahuluan}

Gizi kurang dan gizi lebih sampai saat ini masih menjadi masalah global dunia. Istilah gizi pada umumnya didefinisikan sebagai kejadian obesitas. Obesitas merupakan salah satu masalah masyarakat yang dapat menyebabkan peningkatan jumlah kematian di dunia(1). Menurut World Health Organization (WHO), obesitas adalah penumpukan lemak berlebih di jaringan adiposa pada kelompok anak maupun orang dewasa yang dapat menganggu kesehatan. Prevalensi kejadian obesitas yang tinggi tidak hanya terjadi di negaranegara maju, tetapi juga di negara berkembang termasuk Asia.

Pada tahun 2014, terdapat lebih dari 600 juta orang usia di atas 18 tahun di Indonesia yang mengalami obesitas dan diperkirakan akan terus mengalami peningkatan disetiap tahunnya(2). Kasus obesitas di Indonesia sangat tinggi dan terus meningkat setiap tahunnya. Menurut data RISKESDAS (2013), diketahui bahwa dari sebanyak 649.625 orang dewasa, 7,8\% laki-laki dan 15,5\% perempuan mengalami obesitas pada periode 2010. Persentase tersebut mengalami peningkatan pada tahun 2013 menjadi 19,7\% kasus obesitas pada laki-laki dan 32,9\% pada perempuan(3).

Berdasarkan profil kesehatan provinsi Jawa Tengah (2015), terdapat beberapa kabupaten/kota yang memiliki kasus obesitas yang cukup tinggi. Pada tahun 2015 terdapat 561,709 kasus yang terdiri dari 341,281 kasus pada laki-laki $(24,04 \%)$ dan 341,281 kasus pada wanita obesitas diatas umur 15 tahun (25,82\%). Kabupaten atau kota dengan persentase obesitas tertinggi terdapat di Kota Salatiga yaitu sebesar $71,18 \%$ (41,994 kasus), kemudian Kabupaten Magelang 65,02\% (31,208 kasus) dan Kabupaten Karanganyar 64,86\% (29,917 kasus(4). 
Kegemukan atau obesitas memiliki faktor risiko yang dapat meningkatkan risiko penyakit tidak menular (degeneratif) seperti penyakit jantung koroner, diabetes melitus tipe 2, hipertensi, dan dislipidemia. Obesitas memiliki persentase kemungkinan menyebabkan penyakit lain yaitu hipertensi sebanyak 2,5 kali, diabetes 4,5 kali, dan penyakit jantung koroner sebesar $32 \%(5)$. Hal tersebut didukung pula oleh Hardman and Stensel (2003) yang menyatakan bahwa obesitas merupakan salah satu penyebab terjadinya hipertensi(6). Obesitas dapat menyebabkan penyakit hipertensi lebih banyak dari pada orang yang memiliki berat badan normal. Hal tersebut didukung dari penelitian Black HR \& Sica AD (2008) bahwa dari $60 \%$ penderita hipertensi sekitar $20 \%$ diantaranya mempunyai berat badan berlebih(7).

Di Indonesia, penyakit hipertensi masih merupakan tantangan besar yang sering ditemukan pada pelayanan kesehatan. Berdasarkan Riskesdas 2013, prevalensi hipertensi di Indonesia sebesar 25,8\% yang berarti bila jumlah penduduk Indonesia tahun 2013 sebesar 252.124.458 jiwa maka terdapat 65.048.110 jiwa yang menderita hipertensi (3), Berdasarkan hasil pemeriksaan tekanan darah tahun 2015 di seluruh Indonesia, persentase tertinggi terdapat di Kota Salatiga yaitu sebesar 41,52\% dan kasus hipertensi di Salatiga pada tahun 2015 mencapai 16,19\%(8). Menurut Profil Kesehatan provinsi Jawa Tengah tahun 2015, tingginya kasus obesitas dan hipertensi disebabkan oleh pola makan yang salah(4). Menurut Sulistyoningsih tahun 2011 pola makan yang tidak teratur dan tidak terkontrol serta makan dengan porsi berlebih dan secara terus-menerus hingga menjadi suatu kebiasaan akan menyebabkan obesitas(9). Pola makan juga merupakan salah satu faktor risiko terjadinya hipertensi(10). Berdasarkan uraian di atas maka tujuan dari penelitian ini adalah untuk mengetahui gambaran pola makan lansia penderita obesitas di wilayah kerja Puskesmas Tegalrejo, Kota Salatiga

\section{Metode}

Jenis penelitian ini adalah deskriptif kuantitatif. Responden penelitian adalah lansia berusia $\geq 50$ tahun baik laki-laki maupun perempuan, terdiagnosa secara medis memiliki hipertensi selama 2 tahun terakhir (2016 - 2017), mengikuti Posyandu Lansia setiap bulan di Wilayah kerja Puskesmas Tegalrejo, Kota Salatiga, serta bersedia menjadi responden penelitian untuk penelitian ini.

Penelitian ini dilakukan pada 22 kelompok posyandu di wilayah kerja Puskesmas Tegalrejo. Penelitian ini dilaksanakan pada bulan FebruariApril 2018, meliputi 3 wilayah di Kota Salatiga, yakni Kumpulrejo, Tegalrejo, dan Randu acir. Data yang dikumpulkan berupa data primer dan data sekunder. Pengumpulan data primer dilakukan dengan melakukan pengisian kuisioner, meliputi karakteristik responden, pengetahuan responden terkait obesitas dan hipertensi, dan pola konsumsi responden dengan pengisian Food Frequency Questionnaire (FFQ) dan Food Recall. Perolehan data sekunder berasal dari hasil pencatatan dan pelaporan posyandu Lansia di Puskesmas Tegalrejo, Kota Salatiga dan untuk mengetahui status gizi lanjut usia digunakan perhitungan rumus Indeks Massa Tubuh (IMT) serta tekanan darah.

Analisis data meliputi hasil kuesioner dari itemitem pertanyaan yang disediakan, kemudian dianalisis secara deskriptif; lembar FFQ dan Food Recall dianalisis untuk mendapatkan data terkait jenis makanan yang rutin dikonsumsi dalam kurun waktu pengamatan penelitian, frekuensi, jumlah takaran, cara pengolahan, serta penghitungan zat gizi dan kalori. Data yang telah terkumpul disunting terlebih dahulu terkait kelengkapan dan kesinambungan data, baik data yang terkumpul dari pengisian kuesioner, FFQ, Food Recall, maupun data sekunder yang diperoleh dari Puskesmas Tegalrejo, Kota Salatiga (tahapan reduksi data). Data-data tersebut selanjutnya ditampilkan secara deskriptif dalam bentuk tabel berupa presentase. Langkah terakhir adalah melakukan pembahasan berdasarkan hasil penelitian dan penarikan kesimpulan sesuai dengan tujuan penelitian.

\section{Hasil \& Pembahasan}

Berdasarkan Tabel 1, sebagian besar responden lanjut usia berjenis kelamin wanita sebanyak 53 orang $(92,98 \%)$ dan pria sebanyak 4 orang $(7,02 \%)$. Sebagian besar lansia yang menjadi responden pada rentan usia 60 - 69 tahun sebanyak 28 orang $(49,12 \%)$, rentang usia $50-59$ tahun sebanyak 19 orang $(33,33 \%)$, dan usia $>70$ tahun sebanyak 10 
Tabel 1 | Data Frekuensi data umum responden

Karakteristik Responden

Jumlah

Persentase

(n)

(\%)

Jenis Kelamin

$\begin{array}{lcc}\text { Pria } & 4 & 7,02 \\ \text { Wanita } & 53 & 92,98\end{array}$

Usia

\begin{tabular}{lll} 
50-59 Tahun & 19 & 33.33 \\
\hline 60-69 Tahun & 28 & 49.12 \\
\hline$>70$ Tahun & 10 & 17.54
\end{tabular}

Berat Badan

$\begin{array}{lcc}50-59 \mathrm{~kg} & 7 & 12.28 \\ 60-69 \mathrm{~kg} & 31 & 54.39 \\ >70 \mathrm{~kg} & 19 & 33.33\end{array}$

Riwayat Obesitas

\begin{tabular}{lll}
\hline Ada & 22 & 38,59 \\
\hline Tidak & 37 & 64,91
\end{tabular}

Riwayat Hipertensi

\begin{tabular}{|lll}
\hline Ada & 34 & 59,64 \\
\hline Tidak & 23 & 40,36 \\
\hline
\end{tabular}

\section{Lamanya Menderita}

Hipertensi

$\begin{array}{lcc}2-5 \text { tahun } & 49 & 85,96 \\ >5 \text { tahun } & 8 & 14,04\end{array}$

Tabel 2 menunjukan tingkat asupan zat gizi yang didapatkan dari hasil Food Recall 24 jam dikategorikan dengan tabel kategori kecukupan gizi (Depkes, 1996) dengan 5 kategori yaitu > 120\% (diatas kebutuhan), 90119\% (normal), 80-89\% (defisit ringan), $70-79 \%$ (defisit sedang), dan $<70 \%$ (defisit berat). Hasil penelitian menunjukkan bahwa konsumsi energi terbanyak pada kategori defisit berat yaitu sebanyak 54 orang $(94,7 \%)$, konsumsi protein sebanyak 48 orang $(84,21 \%)$ masuk dalam kategori defist berat, serta konsumsi lemak terbanyak pada kategori defisit berat sebanyak 38 orang $(66,67 \%)$ dan sebanyak 12 orang $(21,05 \%)$ masuk dalam kategori normal. Konsumsi karbohidrat terbanyak masuk dalam kategori defisit berat yaitu sebanyak 52 orang (91,23\%).

Berdasarkan Tabel 3 didapatkan bahan makanan dengan rata-rata konsumsi terbanyak yaitu beras dengan jumlah 14 kali/minggu untuk makanan pokok. Bahan makanan

orang (17,54\%). Sebagian besar responden memiliki berat badan antara 60 - 69 kg (54,39\%) dan Responden tidak memiliki riwayat obesitas yakni sebanyak 37 orang $(64,91 \%)$ dan responden memiliki riwayat hipertensi sebanyak 34 orang $(59,64 \%)$. Sebanyak 49 orang $(85,96 \%)$ sudah mengalami hipertensi selama 2-5 tahun terakhir dan sebanyak 8 orang $(14,04 \%)$ sudah mengalami hipertensi $>5$ tahun terakhir. sumber lauk hewani yang paling banyak dikonsumsi yaitu telur ayam 5 kali/minggu dan bahan makanan sumber lauk nabati yaitu tahu 12 kali/minggu. Bahan Makanan dari sayuran yang paling sering dikonsumsi yaitu bayam 3 kali/minggu, minuman yaitu teh 7 kali/minggu dan gorengan $14 \mathrm{kali} / \mathrm{ming}$ gu.

Berdasarkan hasil Tabel 4 terkait kategori pengetahuan lansia diperoleh hasil yaitu bahwa pengetahuan dari 57 responden di Wilayah kerja

Tabel 2 | Distribusi Tingkat Asupan Gizi (Energi, Protein, Lemak, dan Karbohidrat) Lansia $>\mathbf{5 0}$ tahun di Wilayah Kerja Puskesmas Tegalrejo

\begin{tabular}{lcccccccc}
\multirow{2}{*}{ Keterangan } & \multicolumn{2}{c}{ Energi } & \multicolumn{2}{c}{ Protein } & \multicolumn{2}{c}{ Lemak } & \multicolumn{2}{c}{ Karbohidrat } \\
\cline { 2 - 9 } & $\mathrm{N}$ & $\%$ & $\mathrm{~N}$ & $\%$ & $\mathrm{~N}$ & $\%$ & $\mathrm{~N}$ & $\%$ \\
\hline Di Atas Kebutuhan & 0 & 0 & 1 & 1.75 & 3 & 5,26 & 1 & 1,75 \\
Normal & 1 & 1.75 & 3 & 5.26 & 12 & 21,05 & 0 & 0 \\
Defisit Ringan & 0 & 0 & 1 & 1.75 & 3 & 5,26 & 2 & 5,26 \\
Defisit Sedang & 2 & 3.5 & 4 & 7.01 & 1 & 1,75 & 1 & 1,75 \\
Defisit Berat & 54 & 94.7 & 48 & 84.21 & 38 & 66,67 & 52 & 91,23 \\
\hline
\end{tabular}


Puskesmas Tegalrejo adalah 11 orang (19,30\%) memiliki pengetahuan yang baik, sebanyak 22 orang $(38,60 \%)$ memiliki pengetahuan cukup baik, dan 24 orang $(42,11 \%)$ memiliki pengetahuan kurang baik.

Berdasarkan kuisioner diet yang dilakukan terhadap 57 responden sebanyak 18 orang $(31,58 \%)$ mengurangi konsumsi sumber karbohidrat, 22 orang $(38,60 \%)$ mengurangi konsumsi lemak, 56 orang $(98,25 \%)$ mengurangi konsumsi garam, serta 8 orang $(14,04 \%)$ mengurangi frekuensi makan.

\section{Gambaran Karakteristik Responden Di}

\section{Puskesmas Tegalrejo}

Berdasarkan Tabel 1, jumlah responden pria lebih tinggi $(7,02 \%)$ dibandingkan dengan wanita (92,98\%). Kecenderungan bahwa kejadian obesitas umumnya kerap ditemui pada wanita didukung oleh data RISKESDAS tahun 2013 yang menyatakan bahwa obesitas lebih banyak terjadi pada wanita (32,9\%) dibandingkan dengan pria $(19,7 \%)(3)$. Profil Kesehatan Jawa Tengah tahun 2015 menyebutkan bahwa angka kejadian obesitas lebih tinggi terjadi pada wanita $(25,82 \%)$ daripada pria (24,04\%)(4). Kondisi serupa terjadi pula pada kasus hipertensi menurut RISKESDAS 2013 bahwa kejadian hipertensi pada wanita lebih dominan $(28,8 \%)$ dibandingkan pada kelompok pria $(22,8 \%)$.

Pada penelitian ini, persentase tertinggi lansia yang mengalami obesitas dan hipertensi terdapat pada responden yang berusia $>60$ tahun $(49,12 \%)$. Pada penelitian ini, persentase tertinggi lansia yang mengalami obesitas dan hipertensi terdapat pada responden yang berusia $>60$ tahun $(49,12 \%)$. Umur

Tabel 3 | Distribusi bahan makanan 3 bulan berdasarkan Frekuensi yang paling sering dikonsumsi Lansia $>\mathbf{5 0}$ tahun di Wilayah Kerja Puskesmas Tegalrejo

\begin{tabular}{llc} 
Bahan Makanan & Jenis Makanan & $\begin{array}{c}\text { Frekuensi } \\
\text { (kali/minggu) }\end{array}$ \\
\hline Makanan Pokok & Nasi & 14 \\
Lauk Hewani & Telur ayam & 5 \\
Lauk Nabati & Tahu & 12 \\
Sayuran & Bayam & 3 \\
Buah-buahan & Pisang & 4 \\
Minuman & Teh & 7 \\
Selingan & Gorengan & 14
\end{tabular}

merupakan salah satu faktor yang mempengaruhi tekanan darah, semakin tua seseorang maka semakin beresiko terserang hipertensi (11). Penelitian hasurung dalam Rahajeng dan Tuminah (2009) menemukan bahwa pada lansia 60-64 tahun terjadi peningkatan resiko hippertensi sebesar 2,18 kali (12). Pada kategori lanjut usia tubuh akan mengalami penurunan massa otot dan perubahan hormon sehingga terkadi penurunan metabolisme dalam tubuh. Penurunan massa otot ini merupakan dampak dari menurunnya aktivitas fisik sehingga kemungkinan untuk terjadi obesitas lebih besar (13).

Responden yang tidak memiliki riwayat obesitas lebih banyak $(64,91 \%)$ daripada responden yang memiliki riwayat $(38,19 \%)$, sedangkan responden yang memiliki riwayat hipertensi lebih banyak $(59,64 \%)$ dari pada yang tidak memiliki riwayat $(40,36 \%)$. Seseorang yang memiliki faktor keturunan obesitas, maka di dalam tubuh mereka akan menghasilkan lemak tubuh lebih banyak dibandingkan dengan yang tidak memiliki riwayat. Pada sebuah studi disebutkan bahwa bila kedua orang tua obesitas maka anak mempunyai kemungkinan $80 \%$ untuk menjadi obesitas, jika salah satu orang tuanya overweight atau obesita maka anak akan mempunyai kemungkinan $40 \%$ untuk obesitas(14) dan seseorang yang memiliki riwayat hipertensi dari kedua orang tuanya juga akan berisiko terkena hipertensi yang disebabkan karena pengaruh genetika(15).

\section{Gambaran Food Recall, FFQ, Pengetahuan Responden terhadap Obesitas dan Hipertensi}

Asupan zat gizi terdiri dari energi, protein, lemak, dan karbohidrat. Asupan makanan tersebut akan digunakan oleh tubuh untuk melakukan aktivitas harian. Asupan makanan sangat berhubungan dengan pola makan. Pola makan

Tabel 4 | Tingkat pengetahuan responden

\begin{tabular}{|c|c|c|c|}
\hline Variabel & $\begin{array}{c}\text { Kategori } \\
\text { Nilai }\end{array}$ & Frekuensi & $\begin{array}{c}\text { Persentase } \\
\text { (\%) }\end{array}$ \\
\hline Baik & $>80 \%$ & 11 & 19,30 \\
\hline Cukup Baik & $60-80 \%$ & 22 & 38,60 \\
\hline Kurang Baik & $<60 \%$ & 24 & 42,11 \\
\hline \multicolumn{2}{|c|}{ Total } & 57 & 100 \\
\hline
\end{tabular}


dapat pula memicu terjadinya penyakit yaitu obesitas dan hipertensi. Semakin banyak makanan yang dikonsumsi maka semakin banyak kalori yang akan didapatkan. Apabila seseorang terus mengonsumsi makanan yang banyak mengandung kalori maka dapat menyebabkan terjadinya penumpukan lemak di dalam tubuh.

Berdasarkan hasil asupan karbohidrat, sebanyak $94,7 \%$ responden termasuk ke dalam kategori defisit berat. Kondisi tersebut menunjukkan bahwa sebagian besar responden tidak memiliki asupan karbohidrat yang cukup setiap harinya. Pada umumnya responden mengonsumsi makanan sumber energi sebanyak 3 kali sehari, akan tetapi makanan yang dikonsumsi kurang mencukupi kebutuhan tubuh dalam sehari dan menu makanan tidak beragam, sehingga jumlah asupan energi yang dikonsumsi tidak sesuai dengan kebutuhan. Hal ini juga didukung oleh hasil penelitian yang mengatakan sebanyak 18 orang (31,58\%) melakukan diet dengan mengurangi konsumsi sumber karbohidrat.

Asupan protein responden berasal dari bahan makanan sumber protein hewani dan protein nabati. Berdasarkan evaluasi FFQ, asupan protein hewani dan nabati terbanyak berasal dari telur dan tahu setiap minggunya. Asupan protein yang sesuai dengan rekomendasinya, baik nabati maupun hewani dapat menurunkan tekanan darah jika diikuti dengan perubahan gaya hidup, namun konsumsi makanan protein hewani yang berlebih dapat memicu kolesterol. Kombinasi antara asupan lemak jenuh (kolesterol) dengan protein dapat memicu terjadinya resistensi insulin karena mengandung asam amino arginin, histidin, dan leusin serta berkaitan dengan metabolisme lemak (16), sehingga apabila dikonsumsi secara terusmenerus dapat menyebabkan penumpukan lemak yang menjadi obesitas. Akan tetapi hasil ini bertolak belakang dengan hasil Food Recall yang menunjukkan bahwa asupan protein termasuk ke dalam kategori defisit berat. Kondisi tersebut dapat disebabkan oleh responden yang tidak mengatakan keadaan sebenarnya pada saat melakukan wawancara, sehingga apabila dihitung dengan metode Food Recall mengalami defisit.

Asupan lemak juga sangat berpengaruh terhadap terjadinya obesitas dan hipertensi.
Menurut Black dan Hawaks (2005), faktor-faktor yang mempengaruhi tekanan darah adalah asupan lemak dan status gizi (17). Pola konsumsi masyarakat Indonesia cenderung gemar mengkonsumsi makanan yang digoreng dan bersantan (3). Kebiasaan rutin mengkonsumsi jenis makanan tersebut dapat meningkatkan asupan lemak sehingga menyebabkan penumpukan lemak di dalam tubuh yang akan mengakibtkan obesitas.

Berdasarkan analisa Food Recall, asupan lemak responden tergolong ke dalam defisit berat $(66,67 \%)$. Hasil penelitian ini didukung dari hasil mengenai diet yang dilakukan, sebanyak 22 orang $(38,60 \%)$ mengurangi konsumsi lemak. Hal tersebut menunjukkan bahwa responden sudah melakukan diet lemak akan tetapi diet yang dilakukan keliru karena asupan lemak yang dikonsumsi kurang dari kebutuhan seharusnya.

Asupan karbohidrat responden termasuk ke dalam kategori defisit berat. Para responden sudah mengetahui bahwa mengkonsumsi terlalu banyak karbohidrat dapat menyebabkan obesitas, sehingga responden berupaya untuk mengurangi konsumsi makanan yang mengandung karbohidrat. Sebanyak $31,58 \%$ responden (18 orang) mengaku melakukan diet karbohidrat, namun diet yang dilakukan keliru karena mengurangi asupan makan dan tidak menambah asupan serat. Hal lain yang menjadi penyebab asupan karbohidrat termasuk ke dalam defisit berat adalah karena pada saat wawancara masih banyak responden yang kurang terbuka kepada peneliti sehingga masih ada beberapa makanan yang tidak disebutkan oleh responden. Selain itu, kelemahan dari metode Food Recall 24 jam adalah tidak dapat menggambarkan asupan makanan sehari-hari. Ketepatan dalam penggunaan metode ini bergantung pada daya ingat responden. Penyebab lainnya adalah karena kejadian obesitas dan hipertensi tidak hanya berhubungan dengan pola makan, tetapi juga faktor lain seperti aktivitas fisik, pengetahuan, hormon, riwayat dan fisiologis responden(18). Berdasarkan analisa FFQ, karbohidrat yang bersumber dari nasi masih banyak dikonsumsi oleh responden setiap harinya.

Salah satu faktor yang mempengaruhi pola makan pada lansia adalah pengetahuan. Hasil penelitian yang ditunjukkan pada Tabel 4 
menunjukkan bahwa responden yang mempunyai pengetahuan tinggi cenderung lebih sedikit sehingga masih banyak lansia yang mengonsumsi asupan makanan yang tidak sesuai dengan kebutuhan. Keseluruhan asupan gizi pada lansia termasuk ke dalam kategori defisit berat akibat pola makan yang buruk. Hal tersebut sejalan dengan pendapat Bonaccio et al. (2013) yang menyatakan bahwa seseorang yang memiliki keterbatasan pengetahuan terutama tentang gizi cenderung akan memiliki pola makan yang buruk (19). Menurut Sada et al. (2012), pengetahuan seseorang tentang gizi sangat berpengaruh terhadap asupan dan kebiasaan makan(20), namun berdasarkan hasil wawancara, responden mengetahui bahwa pola makan yang dilakukan keliru dan responden mengetahui bahwa dirinya memiliki riwayat penyakit obesitas dan hipertensi, sehingga responden berupaya untuk mengatasi keadaan obesitas dan hipertensi tersebut dengan cara melakukan diet. Diet yang dilakukan responden pada dasarnya keliru. Responden mengganggap diet yang mereka lakukan adalah mengurangi makanan dan tidak mengkonsumsi makanan yang menjadi pantangan, sehingga hasil dari perhitungan Food Recall menjadi lebih defisit berat.

Berdasarkan hasil penelitian disarankan bagi tenaga kesehatan supaya lebih meningkatkan penyuluhan kepada lansia mengenai pola makan yang sesuai dengan diet rendah lemak dan hipertensi dan bagi masyarakat diharapkan dapat lebih selalu mengontrol tekanan darah, serta pola makan dan menghindari faktor-faktor yang menyebabkan terjadinya penyakit hipertensi dan obesitas.

\section{Kesimpulan}

Berdasarkan evaluasi hasil FR dan FFQ, responden tidak mengkonsumsi makanan atau minuman yang dapat menyebabkan obesitas dan hipertensi, namun berdasarkan pengukuran IMT dan tekanan darah, responden mengalami obesitas dan hipertensi. Kondisi tersebut dipengaruhi oleh faktor fisiologis (keturunan, tingkat asupan gizi) dan pengetahuan mengenai pola makan. Responden paham bahwa dirinya mengalami obesitas dan hipertensi, lalu berupaya untuk mengatasi hal tersebut melalui diet, akan tetapi diet yang dilakukan keliru, sehingga hasil penghitungan terhadap distribusi tingkat asupan gizi untuk energi, protein, lemak, dan karbohidrat termasuk ke dalam kategori defisit berat.

\section{Bibliografi}

1. Misnadiarly, (2007), Obesitas Sebagai Faktor Risiko Beberapa Penyakit. Jakarta: Pustaka Obor Populer

2. World Health Organization, (2015), World Health Statistics 2015. Current Opinion in Genetics and Development. Vol. 46, page: 50-57 .

3. Badan Penelitian dan Pengembangan Kesehatan. Riset Kesehatan Dasar (RISKESDAS) (2013). Lap Nas 2013. 2013;1-384.

4. Dinas Kesehatan Provinsi Jawa Tengah. (2015). Profil Kesehatan Provinsi Jawa Tengah 2015. Dinas Kesehatan Provinsi Jawa Tengah.

5. Bogers R. P, Bemelmans W. J \& H. R. et al. (2007). Association of Overweight With Increased Risk of Coronary Heart Disease Partly Independent of Blood Pressure and Cholesterol Levels: A Meta-analysis of 21 Cohort Studies Including More Than 300000 Persons. Arch Intern Med;167(16):1720-8.

6. Hardman, A. E \& Stensel D. J, (2003), Physical Activity and Health. New York; Routledge Taylor \& Francis Group

7. Black H. R \& Sica A. D, (2008), Hypertension Primer, The Essentials of High blood pressure,editor. Philadelphia: Lippincott Williams \& Wilkins; Blood pressure in children; Volume 83.4. pp. 273-275.

8. Arief. Profil hipertensi pada populasi MONICA tahun 2000 (survey III) In 2007. Available from: http://www.pjnhk.go.id

9. Sulistyoningsih. H, (2011), Gizi untuk kesehatan ibu dan anak. Yogyakarta: Graha IImu;. hlm. 235-237

10. Solehatul Mahmudah, Taufik Maryusman, Firlia Ayu Arini. (2015). Hubungan gaya hidup dan pola makan dengan kejadian hipertensi pada lansia di kelurahan sawangan baru tahun 2015. Biomedika, vol 7. HIm 4352.

11. Khomsan, A. (2003). Pangan dan Gizi Untuk Kesehatan. PT. Rajagrafindo. Persada. Jakarta:95

12. Rahajeng, E., Tuminah, S. (2009). Prevalensi Hipertensi dan Determinannya di Indonesia. Majalah Kedokteran Indonesia. 59(12):580-587

13. Anggraini S. (2008). Faktor Risiko Obesitas Pada Anak Taman Kanak- Kanak Di Kota Bogor. IPB.;1-54.

14. Sutanto. (2010). Cegah \& Tangkal Penyakit Modern. Yogyakarya: Andi 
15. Deborah Bujnowski, Pengcheng Xun, Martha L. Daviglus, Linda Van Horn, Ka He; Jeremiah Stamler. (2011). Longitudinal Association Between Animal And Vegetable Protein Intake And Obesity Among Men In The United States: The Chicago Western Electric Study. American Dietetic Association.;111:1150-1155

16. Murray. R, Granner D. K, Rodwell V. W. (2009). Biokimia. Jakarta: Buku Kedokteran EGC

17. Black, J, M., Hawks, J. H. (2015). Medical Surgical Nursing Clinical Management for Positive Outcome 7th Edition. St Louis : Elsevier Saunder

18. Prasetyaningrum, Yunita Indah. (2014). Hipertensi Bukan untuk Ditakuti. Jakarta: Fmedia. 